\title{
Fiscal Challenges in Pandemic Times
}

\author{
Stevan Gaber ${ }^{1}$, Ilija Gruevski²
}

UDC 336.02]:616.98:578.834\}-036.21(497.7)

336.27]:616.98:578.834\}-036.21(497.7)

336.5]:616.98:578.834\}-036.21(497.7)

${ }^{1}$ Goce Delcev University, Faculty of Economics, Krste Misirkov St., 10-A, Republic of Macedonia, e-mail: stevan.gaber@ugd.edu.mk

${ }^{2}$ Goce Delcev University, Faculty of Economics, Krste Misirkov St., 10-A, Republic of Macedonia, e-mail: ilija.gruevski@ugd.edu.mk

\section{Abstract}

The unexpected health crises that appeared at the end of 2019 and endures currently had triggered serious government challenges in conducting efficient fiscal policy. The growing health, educational, social, and other costs corelated with the health crisis had raised intense reactions in governments through higher public expenditures that were financed dominantly from international financial markets. Already higher public debt to GDP ratio in some countries overcome the Maastricht criteria of this crucial fiscal variable that raised some serious questions for future government financial responses. This pandemic opened some suggestions and considerations for major or minor tax reforms in some countries. If previously the governments were repellent to introduce some tax changes, now they see opportunity to easily justify this fiscal step. The people subjected to COVID-19 disease are addressing more publicly the need for substantial government help regarding the health costs. The IMF surveys show that people who faced this illness are more demanding for changes in distributional fiscal function. The companies and households with extra profits and income should be taxed with higher income tax rates and corporate taxes. The reason for this demand is the ongoing process of unevenly distributed national income that in pandemic circumstances affects more lower layers of income households. However, the real sector in North Macedonia is publicly against higher tax rates, and they demand from government first to legalize the grey economy that they perceived as serious competitive and fiscal problem.

\section{Keywords}

Covid-19, fiscal policy, public debt, public expenditure, tax policy.

\section{Introduction}

The negative effects of COVID-19 pandemics have been wide and severe, taking hard tolls on human lives, households, businesses, economies and the whole world. Since the declaring it as international health emergency in January 2020 to global pandemics by middle of March 2020, 
there were 6,2 million confirmed cases and 372000 confirmed deaths across 188 countries as of 1 June 2020 [1].

The virus spread raise to be severe challenge to health systems around the globe and becoming the leading purpose for death in the USA. The immanent lockdowns of economies and restricted movement of people in and out of borders led to significant change in people's livelihood. Depending on the pandemics geography the measures are eased or introduced in others. New infections in advanced economies have tendency to decline, while in some developing countries in Asia, Africa Latin America and Middle East tend to increase.

This pandemic caused by COVID-19 raised to be the biggest global recession since the World War II. The lockdowns around the world led to disturbance in global and local supply chains, global trade, travel, and tourism and finally between labor supply and consumer demand. Those conditions were accompanied by capital outflows from emerging markets constricted conditions for financing countries, firms, and households. After the first wave, the commodity prices were declined by the reduction in demand, but after the aggressive monetary and fiscal measures from the advanced countries the prices have shown tendencies to rise to satisfying levels for healthy economic growth. Aside the economic catastrophe everywhere, the unforgettable issue is the unprecedented loss of numerous lives due to this corona virus. The poor and most vulnerable people very affected the strongest of all, which led to negative prospects for future poverty and apparent inequality around the world [2].

Health crise initiated comprehensive use of fiscal measures to protect lives and jobs in economic downturn caused by COVID-19 and to reopen economies in very unpredictable environment. Fiscal measures that were taken by so far were immense, necessary, diversified, and expensive. They helped the countries to neutralize negative effects of the pandemic on health and economy. Despite the high levels of public debt, the immanent support is inevitable to protect people and to start economic recovery. Fiscal steps should be constructed in a way depending on the phases of the pandemics, acting in protection of people, stimulate aggregate demand, overcome the pandemic economic state, and seriously consolidate public debt to secure its sustainability.

The pandemic triggered fiscal response that have not been remembered until now in support of health systems and helping sensitive group of people and firms. The fiscal measures that were presented in September 2020 were around 11,7 trillion \$ globally or $12 \%$ of global GDP. Majority of the measures are consisted of intensified spending or tax expenditures, temporary tax reliefs, subsidies and transfers, loans, guarantees, and equity injections from the government. Obviously, the composition and volume of fiscal measures differs from country to country regarding available fiscal space.

Developed countries and large emerging markets are responsible for the dimension of fiscal answer for three reasons. First, they were hit sooner then other countries and stronger by the crises. Second, their national banks were in position to relief monetary policy and provide incentive and purchase government bonds followed by low rates of inflation due to credibility. Third, their ministries of finance were able to provide finances for larger deficits at low interest rates. However, the response in low income developing countries, the deficits were smaller due to financial constraints. Those measures saved lives and livelihoods. The public health steps were especially important and effective since they gave hope through institutional efficiency and restoring confidence for sooner recovery and reopening of activity. Subsidies and transfers were very important for the vulnerable groups of the society, who spent them largely on consumption, while unemployment benefits helped those persons who lost their job during the crises and sustained their essential needs [3].

More severe economic downfalls and significant job losses were stopped though expansive fiscal support. Additionally, the fall in public revenues was reason for increase of government deficits and public debt at levels that were unimaginable before the crises. Average overall deficits as percentage of GDP rose to $11,7 \%$ for advanced economies, $9,8 \%$ for emerging markets economies, and 5.5 percent for low-income developing countries. The increased budget deficit in 
advanced economies and several emerging market economies led to similar increase in spending and downfall in revenues, while on the other hand in many emerging market economies and lowincome developing countries, it derived from collapse of revenues because of the economic shutdown. In 2021 the budget deficit is expected to be reduced in many countries as the support related to pandemics surpasses, revenues recover, and the unemployment benefits disappear.

\section{Global fiscal responses for overcoming the pandemic}

In order to gradually describe the policies responses, we will start with the suggestions of World Bank Group that are observed through three phases and four pillars, which are designed according to individual countries specific conditions. The relief stage is intended to response quickly to health threats by COVID-19 and produce instant economic, social, and financial impact. With the successful containment of the health crisis and made decisions for reopening the economy and cut of restrictions, the phase of restructuring will follow. That implies improvement in health systems, investments in human capital, financial opportunities for companies, recapitalization of firms and financial institutions. The final third phase emphasizes on the recovery and resilience to build more sustainable, inclusive, and resilient future in new economic post-pandemic circumstances.

The four pillars that reflect the government response to the crises are as following: 1) emergency support from the banks in effort to save lives from the virus; 2) social response from the World Bank for poor and vulnerable people who were impacted by economic consequences from the corona virus; 3) WB response to protect job openings, sustain livelihoods, ensure stable growth of firms and helping them in opening new jobs, solving problems with financial sustainability; 4) support for strengthening institutions, policies and investments that would contribute to rebuilding better or more inclusive and sustainable development.

However, every country will respond according to their macroeconomic indicators and fiscal space which will be crucial if they are considering quick recovery and resilience. Particularly important in fragile economic crisis is public debt management and fiscal transparency, followed by institutional reforms so they could fulfill the pillars posted by WB. The bank as always is helping the countries through various ways - financially and technically - so they could succumb the pandemic crises as soon as possible.

It is evident that fiscal support was inevitable to secure speedy recovery and contain the helath crises and duing so secure people's livelihood. The measures that were most exploited are as follows:

- Public health measures are most important tools for supporting recovery, because they save lives, restore people's beliefs, and intensifies activity [4]. All those countries that responded fast through containment measures, mobility restrictions, large number of tests, intensified public campaigns lost fewer lives to the corona virus and are expected to efficiently manage impacts on economic activity and budget balances.

- fiscal measures not connected to health sector have been used for broader specter of objectives.

- One of the social transfers are cash transfers that have been surprisingly effective in protecting the poor and have had a larger impact on total consumption when targeted to those most in need or most likely to spend, such as the unemployed.

- Unemployment benefits were found to be more effective than "stimulus checks" in targeting those households with a higher propensity to consume commodities [5].

- Cash and in-kind transfers have secured better assistance of sensitive households than unemployment benefits in emerging market and developing economies with larger informal sectors. In many cases, social transfers were introduced to quickly attack the pandemic. 
- Wage subsidies for furloughed workers or businesses with revenue losses have been particularly effective in preserving employment, but if maintained for too long after reopening they could delay the required reallocation in labor markets.

- Loans and guarantees, including through public companies, have aimed to provide liquidity to cash-strapped businesses, but so far, many countries report low take-up (for example, Germany, Italy, United Kingdom). On the supply side, this could reflect administrative capacity constraints or program conditionality; on the demand side it could reflect liquidity buffers in less-affected sectors and firms and the availability of other forms of government support, such as grants and wage subsidies. Private debt overhang and elevated uncertainty are also likely drivers. For small and medium enterprises (SMEs), low utilization can also be attributed to design issues, such as large loan size and low coverage of guarantees. In the euro area, banks reported that government guarantees played a significant role in keeping credit standards favorable for SMEs [6].

- Equity injections have often been necessary to prevent bankruptcies of hard-hit strategic firms, such as national airlines, albeit with the risk of delaying sectoral reallocation that is crucial for the recovery. In some cases (New Zealand, Singapore), governments provided convertible loans to national airlines with options to convert bonds into common equity, which ensures that the risks and rewards are better shared by the state and shareholders [7]. In France, airline support was combined with conditionality on cutting emissions, which helps with "greening" the recovery. Although the green (emissions-reducing) component of fiscal responses has been limited, climate-relevant measures may become more prominent as countries shift their attention from the emergency to the recovery.

- Tax measures in response to the pandemic have consisted largely of deadline extensions and payment deferrals that have supported household and firm liquidity, albeit to a lesser extent than debt moratoriums and wage subsidies, given that tax burdens are already limited by lower sales and profits [8]. Moreover, these deferred taxes may not be recovered in full if they are merely delaying severe cash flow problems, creating fiscal risks for governments. Tariff waivers on medical supplies (Colombia, Vietnam) -although tariff rates are already low in many countries-and quick release procedures at customs (Philippines) have expedited imports of essential goods. Accelerated VAT refunds (France, Indonesia), new and expanded loss carryback rules (China, New Zealand, Japan), and accelerated depreciation deductions (Australia) have eased business cash flow needs. Reduced social security contributions (Argentina, China, France, Korea) have protected the most vulnerable and affected households and firms. Nevertheless, tax-based support may be less effective in some emerging market and developing economies because of its limited reach to informal sectors.

- Payment forbearance policies, on the other hand, such as moratoriums facilitated by government support or public enterprises on payments of mortgages (United States), utilities (Argentina, Colombia, Japan), rents (China), or loans (Argentina, Turkey) have provided short-term relief to households and businesses, including in informal sectors.

\section{Fiscal policy in North Macedonia during COVID-19}

In North Macedonia the first wave of corona cases were noticed in fevruary 2020 and the country was not prepared for this kind of health crises. Obviously, the long needed reforms in health sector and the necessity of investmants for improving helath care stated the obvious that the country will suffer serious consequances. The citizens and the economy were hit hard from this COVID-19 virus. Altough, authorities reacted fast to conteain any further spread of the virus and to neutralize 
the negative effects from the restrictions of the economy, the tax was paid with a lot of lives lost to this disesase [9].

The virus hit hardest the most vulnerable collectives, the poor and unemployed, which regarding the size of the economy and its social and economic variables are a large number of the population. Also, serious damages were inflicted to service sector, transport, tourism, which obviously depand a lot on global trade flows and finance. In order to contain the pandemic and restore economic and social life, it is inevitable to prepare and strenghten the capabilities of cricial institutions through which the government could design policy measures and time frame for efficiant combat. However, other no more important thing is the publics perception and reaction to the public sector decision and efficency of public administration.

The initail case in North Macedonia was noticed on 26.2.2020 and in the next 3 months until 29 june, the country registered 6092 cases (2933 cases per million inhabitants) and sadly 286 deaths (138 per million inhabitants). However, the situation in the country took a downfall in May. On 26.5.2021 the country counted 154640 cases (or 74454 per million inhabitants) and the second highest number of COVID-19 deaths in the region with 5337 deaths (or 2570 per million inhabitants) (Figure 1) [10].

\section{Cumulative number of confirmed COVID-19 deaths per million inhabitants}

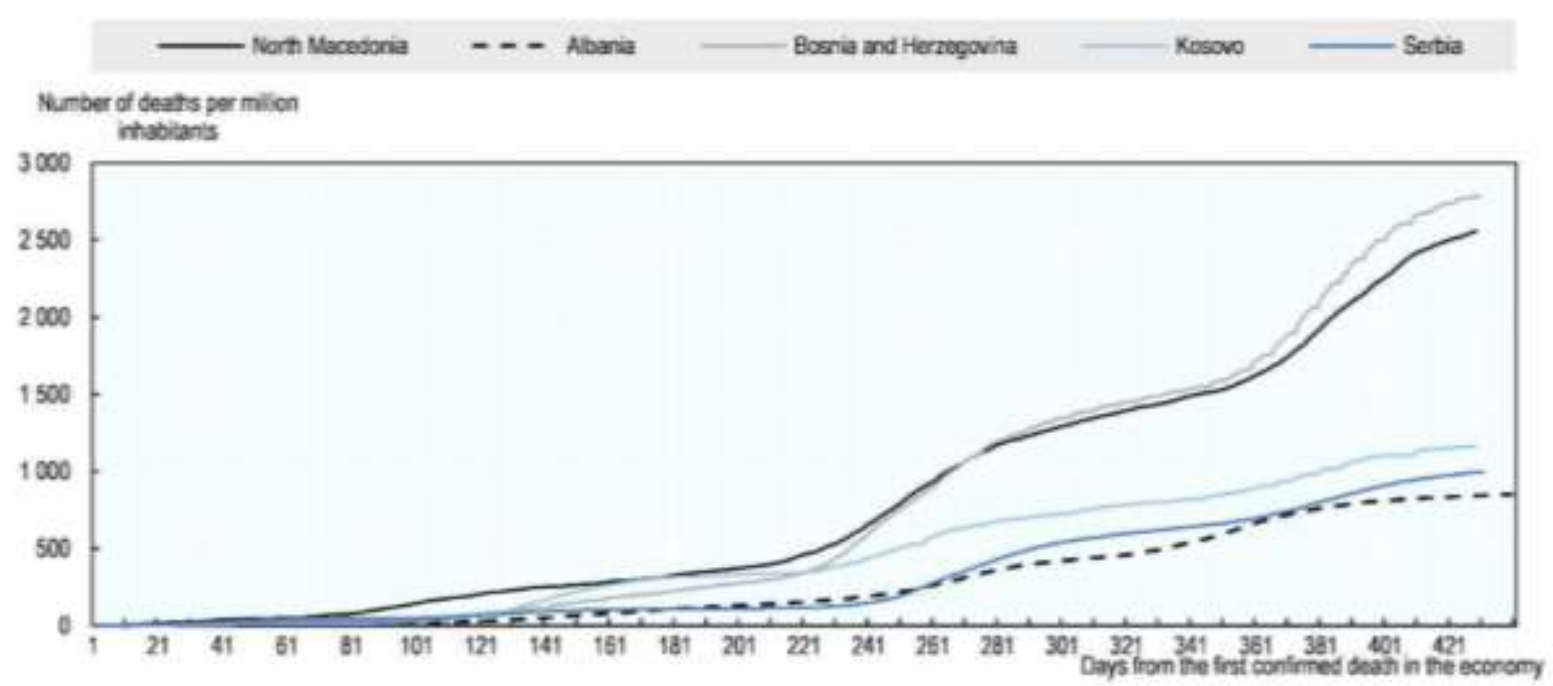

Figure 1. North Macedonia reported the second-highest number of COVID-19 registered deaths per million inhabitants in the Western Balkans.

The government took decisive measures to contain the disbursement of the virus, but they cannot know with certainty future health resilience. Three weeks after the first announced case, it was declared 30 days statewide emergency, restricting public gatherings and movement of people. Curfew was implemented as of 22 March, which was followed with schools shutting down, cultural premises, restaurants, non-critical stores, and borders. Food stores and pharmacies were allowed to continue with work. The elections were postponed to 15 July and this year's statistical operation for register of people was postponed for autumn 2021. As of latest available data, North Macedonia has conducted 373491 tests per million since the start of the pandemic. Test activity is crucial in detecting new cases and in strengthening the economy's health resilience. North Macedonia is following behind in the process of vaccination with only 2 people fully vaccinated per hundred inhabitants, which ls second lowest in the region. 
After the evidently unortodox health and economic crises, the government responded adequtly in effort to neutralize the negative effects from this non-economic factors. That was done by announcing four packages of policy measures that should facilitate and secure as many as posible employments. The first two packages were implemented between March and May 2020 and were inteded to revive the economy and to give boost to the health sector. In the middle of May was presented the third package in amount of 335 million EUR in order to give stimulus to the economy and especialy consumption. The total financial aid for the economy with these three packages was 550 million EUR or $5,5 \%$ of GDP. The current fourth package was introduced on 24.9.2020 and is worth about 470 million EUR.

Table 1. Announced Policy Measures

\begin{tabular}{|c|c|c|c|}
\hline & People & Businesses & Other measures \\
\hline $\begin{array}{l}1^{\text {st }} \text { and } 2^{\text {nd }} \text { package } \\
\text { implemented from } \\
\text { March to May } 2020\end{array}$ & $\begin{array}{l}\text { - Setting up } \\
\text { unemployment } \\
\text { insurance system for } \\
\text { employees who lost } \\
\text { their jobs due to the } \\
\text { health crises. The } \\
\text { state paid a monthly } \\
\text { allowance of } 50 \% \text { of } \\
\text { the average monthly } \\
\text { net salary. } \\
\text { - For citizens who lost } \\
\text { their jobs or were } \\
\text { part of the informal } \\
\text { economy, providing } \\
\text { accelerated access } \\
\text { to the social } \\
\text { protection system for } \\
\text { April and May. } \\
\text { Postponing rent } \\
\text { payments on social } \\
\text { housing. }\end{array}$ & $\begin{array}{l}\text { - A three-month fiscal } \\
\text { package (0,2\% of } \\
\text { GDP) to help address } \\
\text { firms liquidity } \\
\text { problems and protect } \\
\text { jobs, targeted at } \\
\text { transport, tourism, } \\
\text { and catering, starting } \\
\text { in April. } \\
\text { - A salaries support } \\
\text { programme } \\
\text { subsidizing } \\
\text { contributions for } \\
\text { employees in the } \\
\text { tourism, transport, } \\
\text { and catering sectors } \\
\text { up to maximum of } \\
\text { MKD } 14500 \text { (EUR } \\
\text { 235) per month and } \\
\text { per employee for } \\
\text { April, May, and June. } \\
\text { - Credit support } \\
\text { measures: new credit } \\
\text { risk methodology } \\
\text { introduced by the } \\
\text { National Bank to } \\
\text { promote more } \\
\text { favorable credit } \\
\text { standards for } \\
\text { companies affected } \\
\text { by the COVID-19 } \\
\text { crises and to ease } \\
\text { the standards for } \\
\text { household and } \\
\text { corporate loan } \\
\text { restructuring. } \\
\text { - The Development } \\
\text { Bank of North } \\
\text { Macedonia issued a } \\
\text { first set of interest- } \\
\text { free loans for MSMEs } \\
\text { worth EUR } 137\end{array}$ & $\begin{array}{l}\text { - Scaling up of public } \\
\text { health measures, } \\
\text { adopting protocols } \\
\text { for treatment of } \\
\text { COVID-19 cases } \\
\text { and mobilizing the } \\
\text { necessary medical } \\
\text { and health staff and } \\
\text { equipment (e.g., } \\
\text { mechanical } \\
\text { respirators) from } \\
\text { public and private } \\
\text { health facilities. } \\
\text { Public call for the } \\
\text { procurement of } \\
\text { respirators. } \\
\text { On } 16 \text { March } 2020, \\
\text { the National Bank of } \\
\text { NM cut its policy rate } \\
\text { by } 0.25 \% \text { to } 1.75 \% \text {. } \\
\text { On } 13 \text { May } 2020, \text { the } \\
\text { policy rate was cut } \\
\text { further to } 1.50 \% \text {. The } \\
\text { National Bank } \\
\text { reduced the offer of } \\
\text { the Central Bank } \\
\text { Bills by MKD } 15 \\
\text { billion and increased } \\
\text { the liquidity of the } \\
\text { banking sector. It } \\
\text { also revised its credit } \\
\text { risk regulation to } \\
\text { encourage banks to } \\
\text { restructure loans } \\
\text { temporarily and } \\
\text { relaxed the loan } \\
\text { classification } \\
\text { standards for non- } \\
\text { performing loans. In } \\
\text { addition, it reduced } \\
\text { the base for the } \\
\text { reserve reguirement }\end{array}$ \\
\hline
\end{tabular}




\begin{tabular}{|c|c|c|c|}
\hline & & $\begin{array}{l}\text { million (EUR } 5.7 \\
\text { million + EUR } 8 \\
\text { million) - up to EUR } \\
90000 \text { per } \\
\text { enterprise, depending } \\
\text { on the number of } \\
\text { employees. }\end{array}$ & $\begin{array}{l}\text { for firms in affected } \\
\text { sectors. } \\
\text { - The government } \\
\text { signed a decree that } \\
\text { facilitates } \\
\text { procedures in banks. }\end{array}$ \\
\hline $3^{\text {rd }}$ package & $\begin{array}{l}\text { - Distributing payment } \\
\text { cards credited with } \\
\text { MKD } 3000 \text { for low- } \\
\text { paid employees to } \\
\text { stimulate } \\
\text { consumption of } \\
\text { domestic goods and } \\
\text { services. } \\
\text { - Providing support to } \\
\text { students: up to MKD } \\
6000 \text { to cover tuition } \\
\text { fees, a payment card } \\
\text { of MKD } 3000 \text { and } \\
\text { co-financing } \\
\text { vouchers of up to } \\
\text { MKD } 30 \text { 000 for IT } \\
\text { and digital skills } \\
\text { training. The } \\
\text { measure is } \\
\text { estimated to affect } \\
100000 \text { students } \\
\text { and is worth about } \\
\text { EUR } 12 \text { million. } \\
\text { Vouchers for home } \\
\text { tourism of MKD } \\
6000 \text {. } \\
40 \% \text { of base wage } \\
\text { reward for medical } \\
\text { staff. }\end{array}$ & $\begin{array}{l}\text { - Support for the } \\
\text { agriculture sector: } \\
\text { package of measures } \\
\text { supporting agriculture } \\
\text { amounting to EUR } \\
76.1 \text { million. } \\
\text { Measures include } \\
\text { support to micro } \\
\text { enterprises and } \\
\text { SMEs and direct } \\
\text { support to green oil } \\
\text { farmers and grape } \\
\text { processors. } \\
\text { - The Development } \\
\text { Bank of North } \\
\text { Macedonia will } \\
\text { unblock interest-free } \\
\text { loans worth EUR } 31 \\
\text { million. This credit } \\
\text { line will be available } \\
\text { to all micro and small } \\
\text { companies. The } \\
\text { Development Bank } \\
\text { will also offer a non- } \\
\text { refundable } 30 \% \text { grant } \\
\text { for companies that } \\
\text { are run or founded by } \\
\text { women or employ } \\
\text { young people, are } \\
\text { export-oriented or } \\
\text { introduce innovation } \\
\text { and digitalization in } \\
\text { their operations. } \\
\text { - State guarantees for } \\
\text { commercial loans and } \\
\text { customs debt: a } \\
\text { support for start-ups } \\
\text { and small and micro } \\
\text { companies through } \\
\text { commercial banks; } \\
\text { EUR } 10 \text { million of } \\
\text { initial capital for } \\
\text { easier access to } \\
\text { funds will be granted, } \\
\text { mainly by taking part } \\
\text { in the credit risk. }\end{array}$ & \\
\hline
\end{tabular}




\begin{tabular}{|c|c|c|c|}
\hline $4^{\text {th }}$ package & 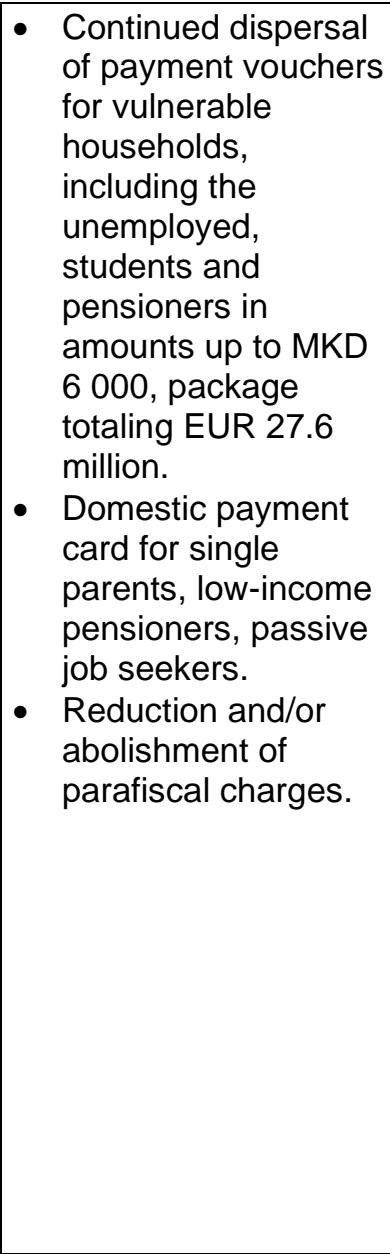 & $\begin{array}{l}\text { - Support programme } \\
\text { for salary payments } \\
\text { extended until the } \\
\text { end of } 2020 \text {, adjusted } \\
\text { for the decline in } \\
\text { revenue for } \\
\text { companies covered } \\
\text { by this measure. } \\
\text { - 3-month extension of } \\
\text { the grace period on } \\
\text { interest-free loans for } \\
\text { existing lines of } \\
\text { credit. } \\
\text { - A package totaling } \\
\text { EUR } 100 \text { million will } \\
\text { be made available to } \\
\text { domestic companies } \\
\text { through the provision } \\
\text { of favorable loan at } \\
\text { low interest rates. } \\
\text { - A state credit } \\
\text { guarantee was } \\
\text { activated, offering } \\
\text { EUR } 10 \text { million in } \\
\text { financial resources to } \\
\text { support companies } \\
\text { through taking partial } \\
\text { responsibility of their } \\
\text { credit risk. } \\
\text { Deferred payment of } \\
\text { VAT for companies. }\end{array}$ & $\begin{array}{l}\text { - Refund of the tourist } \\
\text { tax collected in } 2019 \\
\text { to } 5000 \text { businesses. } \\
\text { - Decrease in VAT for } \\
\text { goods and services } \\
\text { purchased from } \\
\text { artisans in amounts } \\
\text { from } 5 \text { to } 18 \% \text {. }\end{array}$ \\
\hline
\end{tabular}

Sources: OECD (2020), “COVID-19 Policy Tracker", http://oecd.org/coronavirus/en/\#country-policytracker; OECD (2020), The COVID-19 Crises in North Macedonia, www.oecd.org/south-easteurope/COVID-19-Crises-in-North-Macedonia.pdf.

The negative effects on Macedonian economy were substantial. Despite the growth of GDP of $3,9 \%$ in 2019 , the next year 2020 with ongoing health crises the GDP was in downfall of $4,5 \%$. The dominant component of private consumption was reduced for $5,6 \%$, investments by $10 \%$, despite increased public investments in infrastructure in the third quarter. The government took seriously its role and increased government spending by more than $10 \%$. A lot of sectors as I mentioned previously, were affected by the declined economic activity, such as manufacturing, construction, trade, transportation, and tourism. The closed borders and apparent decline in external demand caused decline in export by 10,9\% from GDP, followed also with parallel reduction in imports.

The spring projections of IMF for the growth of the Macedonian economy in 2021 of 3,8\% are close to those of the Ministry of Finance which are set to 4,1\%. Since the start of the year, there are noticeable positive economic performances in the economy. That can be seen at best through the revenue side of the budget. Since the beginning of the year and concluding April, the revenues are higher for $11 \%$ regarding the same period last year, also taking into consideration the fact that last year in most of that period there were no virus implications. The tax and contribution collection are higher for over $12 \%$, where of taxes raised with almost $18 \%$, while contributions have grown for $4,5 \%$. The growth in tax levy is derived from higher rate of collection in almost all duties, and mostly at VAT for almost $30 \%$. 
Currently, in the parlaimant is conducting debate for budget rebalance in which are announced fifth and sixth package for giving the economy the additional boost. According to the Ministry of Finance of North Macedonia, the total public revenues are planned to be 222,6 billion MKD, higher for 10 billion MKD or 4,7\% higher compared to the initial budget projections due to the positive realization of the revenues in the previous year, economic expectiations for 2021, certain changes in tax policy, fair and simplified adiministrative process. The expected growth is $4,1 \%$, and the budget deficit is widend from 4,9 to $6,5 \%$ of GDP [11].

However, the aggressive fiscal policy, represented through increased budget deficit from $2 \%$ of GDP in 2019 to $8,1 \%$ at the end of 2020 , and $6,5 \%$ in 2021 led to substantial rise in public debt of $13 \%$ in period of 1,5 year since the start od pandemics. On 31.3.2021 the public debt of the country is $62,5 \%$ from GDP, while in 2020 was $60,2 \%$, and in $2019-49,4 \%$ of GDP. Current external debt is 5 billion EUR from which only this year the government made 1 billion EUR new debt. This condition of increase in public debt was expected everywhere in Europe [12].

According to IMF, the largest increase in public debt in 2020 compered to 2019 has Spain with $27,5 \%$ or debt of $123 \%$ of GDP, Italy has debt increase of $27 \%$ or public debt of $161,8 \%$ of GDP and Greece with $24,3 \%$ or $205,2 \%$ of GDP. In the region, despite Greece, Albania has largest rise in public debt with $15,6 \%$ or $83,3 \%$ of GDP, Slovenia's debt rises for $14,9 \%$ or $81 \%$ of GDP, and Croatia $14,5 \%$ increase or $87,7 \%$ of GDP. What is essential in issuing new debt is that the price paid for it must be worth it or the growth that will produce must be higher than the interest rate.

All this data show that most of the countries in the world decided to take serious charge on this unprecedented health crises. That resulted in severe rise in public debt in lot of countries, even between those who already had issues with high levels of public debt from GDP. The response obviously was guided by the advanced economies, which in fact was highest and followed by developing countries.

However, most of the developing countries face difficulties regarding the decision from which sources should be financed the large budget deficits. It is currently discussed among the international financial institutions about the intensions to step up and help those countries in need. But also, it is demanded from them to consider changes in tax policies that would help fight the growing inequalities that rose from this crisis. Such changes are already considered in North Macedonia. From the start of 2023 the government intends to implement progressive income tax, reforms in real estate taxes and introduce ecological taxes on fuels. The last one is already underway. The scholars in the country are rigorously against such rise in taxes and demand more serious fight with the informal economy which is very concerning is around $37 \%$. The percentage of $28,6 \%$ total revenue from GDP in 2020 is planned to increase to $31,5 \%$ in 2021 , and total expenditures form 36,7\% to 38\% of GDP in 2021.

\section{Conclusion}

The whole world looks on 2021 as year for economic recovery. With the implementation of the process of immunization and gradual improvement of the epidemic picture, investor and consumer trust will rise, that in return will result with beneficial private consumption and investments. With the recovery of the economies and normalizing the chain of supply, the trade will improve, as well as production capacities. With the relief and suspension of preventive health measures, the service sector could recover intensively. All that could contribute for positive economic activity and economic growth.

Expectations of international financial institutions for global economic result are improving. The spring projections of IMF are higher regarding those in autumn 2020 with expected growth of the economy of $6 \%$ in 2021 and 4,4\% in 2022. Upward revision is derived upon additional fiscal stimulus which was made from several of the largest world economies, on the expected economic recovery in the second half of the year because of the vaccination process, and as of efficiency 
of the measures that were taken by the economies to overcome the circumstances until full vaccination.

The economic growth in the eurozone is projected at 4,4\% for 2021 , which presents slight improvement regarding the projections from January, but corrected downwards compared to October last year. For 2022, the economic growth is projected at 3,8\%, which implies that the expectations are significantly improved regarding those from October last year.

The speed of recovery will depend on region and from country to country according to impact of corona crises and the dynamic of immunization process. Thankfully, the timely policies for containing the negative effects of pandemics, would be expected to leave less consequences than the global financial crises in 2008, but the developing countries and less developed countries, which are with serious impact, is expected to face severe losses on medium term. Uncertainty around recovery it is still immense, mainly due to prolonged health crises, i.e. the delay in vaccination process from arriving of vaccines until to their application, and also raised questions upon their efficiency on new sorts of corona virus. Other sources of uncertainty are effectiveness of economic policies in containing pandemic, development of financial conditions and prices of commodities and services, as the capacity of the economy to adapt.

\section{References}

1. Johns Hopkins Center for Systems Science and Engineering, https://coronavirus.jhu.edu/map.html

2. World Bank Group COVID-19 Crisis Response Approach Paper. Saving Lives, Scaling-up Impact and Getting Back on Track. June 2020.

3. International Monetary Fund, Fiscal Monitor: Policies for the Recovery, October 2020.

4. Chetty, R., J. Friedman, N. Hendren, and M. Stepner. 2020. "How Did COVID-19 and Stabilization Policies Affect Spending and Employment? A New Real-Time Economic Tracker Based on Private Sector Data." Opportunity Insights Working Paper, Harvard University, Cambridge, MA

5. Faria-e-Castro, M. "Fiscal Policy during a Pandemic." Federal Reserve Bank, St. Louis Working Paper 2020-006C. 2020.

6. European Central Bank. "Euro Area Bank Lending Survey." July 14.2020 https://www.ecb.europa.eu/stats/ecb surveys/bank lending survey/html/index.en.html

7. Organisation for Economic Co-operation and Development (OECD). 2020c. "Equity Injections and Unforeseen State Ownership of Enterprises during the COVID-19 Crisis." OECD Publishing, Paris.

8. Organisation for Economic Co-operation and Development (OECD). 2020b. "Corporate Sector Vulnerabilities during the COVID-19 Outbreak: Assessment and Policy Responses." OECD Publishing, Paris.

9. Organisation for Economic Co-operation and Development (OECD). THE COVID-19 CRISIS IN NORTH MACEDONIA. OECD Publishing, Paris. 2021.

10. Our World in Data (2020), Our World in Data website, https://ourworldindata.org/coronavirus.

11. Ministerstvo za finansii na Severna Makedonija. Predlog za izmenuvanje I dopolnuvanje na buzetot na R. Severna Makeddonija za 2021 godina. REBALANS-2021-za-sobranie-09.06.2021-1.pdf (finance.gov.mk)

12. Ministerstvo za finansii na Severna Makedonija. Sostojba na drzaven I javen dolg zaklucno so 3.2021. Состојба на долг - finance.gov.mk 